\title{
Evaluasi Total Koloni Bakteri dan Umur Simpan Telur Asin yang Direndam dalam Larutan Lidah Buaya (Aloevera barbadensis Miller)
}

\section{Evaluation of Bacterial Colony Forming and Shelf Life Salted Eggs with Soaked in Aloe Vera (Aloevera barbadensis Miller) Solution}

\author{
Allismawita, D. Novia dan I. Putra \\ Fakultas Peternakan Universitas Andalas \\ Kampus Unand Limau Manis, Padang 25163 \\ e-mail : deni.novia@gmail.com \\ (Diterima: 03 Januari 2013; Disetujui: 13 Maret 2014)
}

\begin{abstract}
ABSTRAK
Lidah buaya mengandung senyawa antimikroba cukup tinggi ; seperti, aloin $(4,27 \%)$ dan saponin $(5,43 \%)$. Keduanya berguna untuk memperpanjang umur simpan telur asin. Penelitian ini bertujuan untuk mengevaluasi total koloni bakteri dan umur simpan telur asin yang direndam dalam beberapa kosentrasi larutan lidah buaya (Aloevera barbadensis Miller). Materi penelitian ini menggunakan $340 \mathrm{~g}$ garam dapur, $2.000 \mathrm{~g}$ daging lidah buaya yang sudah diblender selama 2 menit didapat $8.896 \mathrm{ml}$ dan air $71.168 \mathrm{ml}$. Penelitian menggunakan metode eskperimen dengan Rancangan Acak Kelompok yang terdiri dari 5 perlakuan dan 4 kelompok. Perlakuannya adalah perbandingan lidah buaya dengan air (V/V) yaitu; A (0:1), B (1:2), C (1:3), D (1:4), dan E (1:5). Peubah yang diamati adalah kadar air, $\mathrm{pH}$, total koloni bakteri dan umur simpan telur asin. Hasil penelitian menunjukan perendaman telur asin dalam larutan lidah buaya menurunkan total koloni bakteri dan umur simpan (berbeda sangat nyata $\mathrm{P}<0,01$ ) dibandingkan kontrol (tanpa perendaman), tetapi perendaman berpengaruh tidak nyata $(\mathrm{P}>0,05)$ terhadap kadar air dan $\mathrm{pH}$. Perlakuan $\mathrm{B}$ (lidah buaya : air $=1: 2$ ) menghasilkan nilai terbaik terhadap kadar air $64,74 \pm 1,60 \%, \mathrm{pH} 7,53 \pm 0,26$, total koloni bakteri $4,79 \pm 0,62 \times 10^{5} \mathrm{CFU} / \mathrm{g}$ dan umur simpan telur asin selama 19 hari.
\end{abstract}

Kata kunci : telur asin, larutan lidah buaya, total koloni bakteri, antibakteri, umur simpan

\section{ABSTRACT}

Aloe vera contains a fairly high antimicrobial compounds such as aloin (4.27\%) and saponin $(5.43 \%)$ which can be used to prolong the shelf life of salted egg. This study aimed at evaluating the bacterial colonies forming and shelf life of salted egg soaked in aloe vera (Aloevera barbadensis Miller) solution. The study material used $340 \mathrm{~g}$ of salt, 2,000 $\mathrm{g}$ of meat blended in aloe vera solution for 2 minutes resulting 8,896 $\mathrm{ml}$ and 71,168 $\mathrm{ml}$ of water. The research method used an experimental approach with randomized block design consisting of 5 treatments and 4 groups. The treatment contained several aloe vera and water $(V / V)$ composition such as; $A(0: 1), B(1: 2)$, $C(1: 3), D(1: 4)$, and $E(1: 5)$. There were a number of measured variables; moisture, $p H$, bacterial colonies forming and shelf life of salted eggs. The results showed that salted egg immersion in a solution of aloe vera decreased the bacterial colonies and shelf life (significantly different $P$ $<0.01$ ) compared to control (no soaking), but its effect was not significant (P>0.05) on moisture and $\mathrm{pH}$. Immersion in a solution of aloe vera (Aloe vera: water 1:2) resulted in the best value on the water content $64.74 \pm 1.60 \%$, pH $7.53 \pm 0.26$, bacterial colonies forming $4.79 \pm 0.62 \times 10^{5}$ $\mathrm{CFU} / \mathrm{g}$ and shelf life of salted eggs was 19 days.

Keywords : salted egg, aloe vera solution, bacterial colonies forming, antibacterial, shelf life 


\section{PENDAHULUAN}

Telur itik termasuk bahan pangan hasil ternak yang sempurna karena mengandung zat gizi yang baik, kaya protein, lemak, mineral, vitamin dan zat lain yang sangat dibutuhkan oleh tubuh. Protein telur merupakan protein yang bermutu tinggi dan sangat mudah dicerna sehingga sangat baik dikonsumsi oleh semua kalangan masyarakat. Telur itik terdiri dari protein $13 \%$, lemak $14 \%$, vitamin dan mineral.

Telur memiliki sifat yang mudah rusak karena kandungan gizi di dalam telur merupakan media yang baik bagi pertumbuhan mikroba, maka diperlukan penanganan untuk mempertahankan kualitas telur tetap baik. Pengawetan telur dengan pengasinan merupakan salah satu cara untuk mempertahankan kualitas telur dan meningkatkan cita rasa telur itik. Proses pengasinan akan menyebabkan adsorbs garam ke dalam telur melalui pori-pori kulit telur. Menurut Arunlertaree (2007) kulit telur itik mempunyai lebih banyak pori dari kulit telur ayam yaitu $0,2-0,4 \mu \mathrm{m}$, dimana struktur pori akan mempengaruhi kapasitas adsorpsi.

Telur asin rebus memiliki umur simpan tiga sampai 7 hari. Salah satu cara untuk memperpanjang masa simpan telur asin yaitu perendaman telur asin dalam larutan lidah buaya (Aloevera barbadensis Miller) yang bersifat sebagai anti bakteri sehingga dapat menghambat masuknya bakteri kedalam telur asin dan dapat memperpanjang masa simpan telur asin. Lidah buaya memiliki komponen kimia yang lengkap yaitu vitamin penting sebagai antioksidan (vitamin $\mathrm{A}, \mathrm{C}, \mathrm{F}, \mathrm{B}$, niacin, $\mathrm{B}_{2}, \mathrm{~B}_{12}$, cholin dan asam folik), enzim (amylase dan lipase), mineral (sodium, potassium, kalsium, magnesium, mangan, chopper, zinc, chromium dan iron), gula, anthraquinon sebagai antimikrobial, sterol, asam salisilik (antiinflamasi dan antibakterial) dan asam amino (delapan asam amino esensial) (Joseph and Justin Raj, 2010).

Hasil penelitian Nejatzadah and Barandozi (2013) lidah buaya dapat menghambat pertumbuhan bakteri gram positif Sigella flexnori dan Streptococcus progenies terutama oleh anthraquinon (aloin) dan dihydroxyanthraquinones (saponin) yang memiliki aktifitas antibakteri. Ditambahkan oleh Narsih et al (2012) kandungan aloin dalam lidah buaya $4,27 \%$ dan saponin $5,43 \%$. Senyawa antibakteri ini akan menghambat pertumbuhan koloni bakteri dan memperpanjang umur simpan telur asin yang dilakukan perendaman dengan larutan lidah buaya jika dibandingkan dengan telur asin biasa. Adapun tujuan dari penelitian ini adalah mengevaluasi total koloni bakteri dan umur simpan telur asin yang direndam dalam beberapa kosentrasi larutan lidah buaya (Aloevera barbadensis Miller).

\section{METODE}

\section{Materi Penelitian}

Penelitian ini menggunakan telur itik segar umur 48 jam yang beratnya 55-65 gram sebanyak 340 butir. Telur itik yang digunakan berasal dari peternak itik di Lubuk Minturun, Padang. Daging lidah buaya yang sudah di blender didapat sebanyak $8.896 \mathrm{ml}$ yang diambil di pekarangan rumah Komplek Taruko 1 Kel. Korong Gadang Kec. Kuranji Padang. Adapun bahan-bahan pengasinan yang digunakan adalah bata merah $4.000 \mathrm{~g}$, abu gosok sebanyak $3.000 \mathrm{~g}$, garam $2.000 \mathrm{~g}$ dan air $71.168 \mathrm{ml}$.

Alat yang digunakan adalah ember plastik, panci, kompor atau alat pamanas, alat pengaduk, stoples atau alat penyimpan dan blender. Peralatan yang digunakan cawan porselen, oven, eksikator, neraca analitik, $\mathrm{pH}$ meter, tabung reaksi, kapas, tissue, cawan petridish, Erlenmeyer, inkubator, autoclave, hockey stik. Sedangkan bahan kimia yang digunakan dalam penelitian ini adalah PCA (Plate Caunt Agar), aquades, peptone, dan alkohol.

\section{Rancangan Penelitian}

Penelitian ini dilaksanakan dengan metode eksperimen dengan Rancangan Acak Kelompok (RAK) yang terdiri dari 5 perlakuan dengan 4 kelompok sebagai ulangan. Sebagai perlakuan adalah perbandingan lidah buaya dengan air (v/v) yaitu, perlakuan A kontrol/direndam air, B (1: 2),C (1: 3), D (1: 4) dan E (1:5). 
Model statistik dari unit rancangan ini menurut Steel dan Torrie (1995):

$$
y i j=\mu+\alpha i+r j+i j
$$

Dimana :

Yij : hasil pengamatan dari unit percobaan yang mendapat perlakuan ke-1, ulangan ke-j

$\mu \quad$ : nilai tengah umum

$\alpha \mathrm{i}:$ pengaruh perlakuan ke-i $(\mathrm{i}=1,2, \ldots 5)$

rj : pengaruh ulangan ke-j $(j=1,2, \ldots 4)$

ij : pengaruh sisa dari unit percobaan yang mendapat perlakuan ke-1 dan kelompok ke-j

i : banyak perlakuan (A, B, C, D, E)

$\mathrm{J}$ : banyak kelompok ulangan $(1,2,3,4)$

Jika perlakuan menunjukkan hasil berbeda nyata $(\mathrm{P}<0,05)$, maka dilakukan uji lanjut dan menggunakan uji Duncan's Multiple Range Test (DRMT) Steel dan Torrie (1995).

\section{Peubah yang Diamati}

Peubah yang diamati adalah kadar air metode oven berdasarkan berat basah, $\mathrm{pH}$ (Apriyantono, et al., 1989), total koloni bakteri berdasarkan pedoman, dan umur simpan menggunakan pengamatan visual dengan parameter sensori (warna, flavor, aroma, rasa dan tekstur). Analisis umur simpan sesuai batas akhir penurunan mutu yang dapat ditolerir yaitu timbulnya lendir pada putih telur, dan bau busuk. Pengamatan umur simpan dilakukan mulai hari ke 6 (kontrol rusak) sampai telur asin busuk (Syarief, et al., 1989).

\section{Prosedur Kerja}

1. Persiapan konsentrasi larutan lidah buaya (Aleovera barbadensis Miller) sebagai berikut : lidah buaya dibersihkan, kemudian kulit lidah buaya dibuka, diambil dagingnya dan diblender selama 2 menit menghasilkan larutan lidah buaya $2224 \mathrm{ml}$ (diulang 4 kali).

2. Prosedur pembuatan telur asin modifikasi Warisno (2005) untuk 1 kali ulangan dalam penelitian ini sebagai berikut: a) telur itik yang telah bersih umur maksimal 2 hari dengan berat 65-75 g sebanyak 85 butir. b) Adonan pengasin yang terdiri dari campuran bata merah 1000 gram, abu gosok 750 gram dan 500 gram dengan perbandingan (3:2:1). c) Kemudian telur dibalur dengan adonan satu persatu secara merata setebal 2 mm. d) Proses pengasinan dilakukan selama 7 hari. e) Setelah perendaman selama 7 hari, baluran telur dibuka, dicuci bersih dan ditiriskan. f) Telur dibagi secara acak menjadi 5 bagian dan direndam dalam 5 perlakuan perbandingan lidah buaya dan air yaitu; A (kontrol/direndam air), B (1:2), C (1:3), D (1:4), E (1:5) dengan volume larutan lidah buaya untuk masing-masing perlakuan $556 \mathrm{ml}$ untuk 17 butir telur, selama 3 hari. g) Setelah perendaman telur asin dibersihkan, kemudian direbus dalam air mendidih sampai telur matang selama 15 menit dan tiriskan dan disimpan pada suhu kamar. h) Kemudian dilakukan pengujian sesuai parameter yang diukur setelah kontrol busuk (hari ke-6). i) Prosedur tersebut diatas diulang sebanyak 4 kali.

\section{Tempat dan Waktu Pelaksanaan}

Penelitian ini dilakukan di Laboratorium Kesehatan Ternak dan Laboratorium Teknologi Hasil Ternak Fakultas Peternakan Universitas Andalas, pada tanggal 02 Agustus 2011 sampai 25 Oktober 2011.

\section{HASIL DAN PEMBAHASAN}

Berdasarkan hasil penelitian didapatkan rataan kadar air, $\mathrm{pH}$ total koloni bakteri dan umur simpan telur asin hasil perendaman dalam larutan lidah buaya dengan perbandingan lidah buaya dan air yang berbeda seperti pada Tabel 1.

\section{Kadar Air}

Hasil penelitian yang telah dilakukan, didapatkan rataan kadar air telur asin yang direndam dalam larutan lidah buaya (Aleovera barbadensis Miller) berkisar antara 64.74 sampai $65.08 \%$. rataan kadar air telur asin pada penelitian ini dapat dilihat pada Tabel 1 .

Hasil analisis keragaman menunjukkan pengaruh yang tidak nyata $(\mathrm{P}>0.05)$ pada perlakuan perbandingan lidah buaya dan air terhadap kadar air telur asin hasil penelitian. Hal ini disebabkan selama perendaman dalam air (kontrol) dan larutan lidah buaya dengan 
Tabel 1. Rataan kadar air, pH, total koloni bakteri dan umur simpan telur asin hasil penelitian

\begin{tabular}{lcccc}
\hline $\begin{array}{l}\text { Perlakuan Perbandingan } \\
\text { Lidah Buaya : Air }\end{array}$ & $\begin{array}{c}\text { Kadar Air } \\
(\%)\end{array}$ & Nilai pH & $\begin{array}{c}\text { Total Koloni Bakteri } \\
\left(1 \times 10^{5}\right) \text { CFU/g }\end{array}$ & $\begin{array}{c}\text { Umur Simpan } \\
\text { (hari) }\end{array}$ \\
\hline A (kontrol) & $65,75 \pm 1,47$ & $7,69 \pm 0,03$ & $37,95 \pm 1,33^{\mathrm{a}}$ & $6,75 \pm 0,50^{\mathrm{e}}$ \\
B (1:2) & $64,74 \pm 1,60$ & $7,53 \pm 0,26$ & $4,70 \pm 0,62^{\mathrm{b}}$ & $19,00 \pm 0,00^{\mathrm{a}}$ \\
C (1:3) & $64,75 \pm 3,90$ & $7,51 \pm 0,35$ & $4,90 \pm 0,81^{\mathrm{b}}$ & $18,00 \pm 0,00^{\mathrm{b}}$ \\
D (1:4) & $64,92 \pm 1,08$ & $7,39 \pm 0,27$ & $5,60 \pm 0,28^{\mathrm{b}}$ & $17,00 \pm 0,00^{\mathrm{c}}$ \\
E (1:5) & $65,08 \pm 1,32$ & $7,36 \pm 0,13$ & $6,45 \pm 0,84^{\mathrm{b}}$ & $16,00 \pm 0,00^{\mathrm{d}}$ \\
\hline
\end{tabular}

Keterangan : Rataan dengan superskrip huruf kecil yang berbeda menunjukkan berbeda sangat nyata $(\mathrm{P}<0,01)$

terhadap kadar air telur asin hasil penelitian. Hal ini disebabkan selama perendaman dalam air (kontrol) dan larutan lidah buaya dengan kosentrasi yang berbeda, sama-sama terjadi sirkulasi air dan udara melalui pori-pori kulit telur. Larutan lidah buaya mengandung tanin dalam jumlah yang sangat sedikit sehingga tidak terjadi proses penyamakan dengan lapisan membran kulit telur sehingga pori-pori kulit telur tetap terbuka.

Menurut Muhammad dan Margareth (2010), lidah buaya berkhasiat sebagai sebagai anti septik, anti jamur dan anti bakteri. Konsentrasi larutan lidah buaya berfungsi membunuh bakteri bukan menutupi pori-pori kulit telur, jadi masih terbukanya pori-pori kulit telur menyebabkan kadar air telur asin yang sudah disimpan selama 6 hari berbeda tidak nyata.

Berbeda tidak nyatanya kadar air perlakuan perendaman dalam larutan lidah buaya (B, C, D dan E) disebabkan penguapan gas dan berkurangnya aktifitas mikroorganisme. Menurut Muchtadi (2009) kerusakan telur diakibatkan oleh keluarnya air dan karbondioksida $\left(\mathrm{CO}_{2}\right)$ dari telur selama penyimpanan. Namun perlakuan direndam air tanpa perendaman pada larutan lidah buaya (A), mengakibatkan aktifitas mikroorganisme akan menghasilkan air. Hal ini sesuai dengan pernyataan Buckle dkk. (2009) bahwa setiap aktifitas mikroba akan menggunakan zat gizi dan komponen lainnya dari produk akhir yang dihasilkan untuk pertumbuhan sehingga aktifitas mikroba tersebut menyebabkan terjadinya pelepasan produk sampingan berupa air.

Hasil penelitian Novia et al. (2011) perendaman telur asin dalam larutan kulit bawang selama 0-7 hari berpengaruh tidak nyata terhadap kadar air dengan kadar air telur asin 67,00-69,00\%. Ditambahkan Novia et al. (2012) telur asin yang direndam dalam air sisa penirisan getah gambir selama 10-50 menit berbeda tidak nyata terhadap kadar air dengan kadar air 66,97-67,60\%. Menurut Harlina et al. (2012) proses pembuatan telur asin dengan menambahkan garlic oil yang mempunyai aktifitas antibakterial dengan persentase garlic oil dan lamanya proses pengasinan (0-28 hari) tidak berpengaruh terhadap kadar air putih dan kuning telur. Nurhidayat (2013) menambahkan proses pemasakan telur asin ayam niaga yang berbeda tidak nyata terhadap kadar air telur asin dengan rataan $71,49 \%$.

\section{Nilai pH}

Hasil penelitian yang dilakukan didapatkan rataan $\mathrm{pH}$ telur asin yang direndam dengan konsentrasi lidah buaya berkisar antara 7.25 sampai dengan 7.53. Rataan $\mathrm{pH}$ telur asin pada penelitian ini dapat dilihat pada Tabel 1 .

Bedasarkan hasil analisis keragaman telur itik hasil penelitian menunjukkan pengaruh berbeda tidak nyata terhadap $\mathrm{pH}$. Berbeda tidak nyatanya nilai $\mathrm{pH}$ telur asin perlakuan perendaman dalam larutan lidah buaya $(B, C$, D dan E) disebabkan oleh $\mathrm{pH}$ larutan lidah buaya hampir sama.

Perlakuan telur asin yang direndam dalam air/kontrol (perlakuan A), dimana poripori kulit telur masih terbuka sampai 6 hari, sehingga bakteri tumbuh secara optimum karena $\mathrm{pH}$ yang didapat yaitu 7.69 sedangkan perlakuan perendaman dalam larutan lidah buaya (perlakuan B, C, D dan E) pHnya akan berada pada kisaran netral karena larutan aloin dan yang ada pada lidah buaya juga tidak 
menutupi pori-pori kulit telur, melainkan berfungsi sebagai anti septik, anti bakteri dan jamur yang dapat mengurangi aktifitas mikroorganisme. Hasil penelitian Novia et al. (2011) perendaman telur asin dalam larutan kulit bawang berpengaruh tidak nyata terhadap $\mathrm{pH}$ dengan kisaran 6,94-7,03.

Menurut Buckle et al. (2009) bahwa kebanyakan mikroorganisme tumbuh pada $\mathrm{pH}$ 5.0 sampai 8.0. Aktifitas mikroorganisme meningkat menyebabkan nilai $\mathrm{pH}$ juga meningkat, tetapi karena larutan aloin dan saponin memiliki $\mathrm{pH}$ yang berkisar antara 7.25 - 7.53 dimana masih kisaran netral maka perendaman telur asin dalam larutan aloin dan saponin tidak berpengaruh terhadap nilai $\mathrm{pH}$ sehingga $\mathrm{pH}$ telur asin masih berada dalam kisaran netral. Nazaruddin (2009) menyatakan, cairan lidah buaya keasaman $(\mathrm{pH})$ seperti kulit manusia.

\section{Total Koloni Bakteri}

Dari penelitian yang telah dilakukan, didapatkan rataan nilai total koloni bakteri telur asin yang direndam dengan konsentrasi larutan lidah buaya (Aleovera barbadensis Miller) berkisar antara 4,7 sampai 6,45 x 10 CPU/g. Rataan total koloni bakteri telur asin pada penelitian ini dapat dilihat pada Tabel 1 .

Hasil analisis keragaman menunjukkan adanya pengaruh berbeda sangat nyata $(\mathrm{P}<0.01)$ perendaman dalam larutan lidah buaya terhadap total koloni bakteri pada telur asin. Hasil uji Duncan's menunjukkan bahwa perendaman memberikan pengaruh berbeda sangat nyata $(\mathrm{P}<0.01)$ terhadap total koloni bakteri.

Pada Tabel 7 dapat dilihat bahwa total koloni bakteri tertinggi terdapat pada perlakuan perendaman dalam air/kontrol (perlakuan A) yaitu $37,95 \times 10^{5} \mathrm{CFU} / \mathrm{g}$, sedangkan total koloni bakteri terendah dapat dilihat pada perlakuan perendaman dalam larutan lidah buaya 1:2 (perlakuan B) yaitu 4,7 x 10 CFU/g. Hasil uji lanjut Duncan's menyatakan bahwa perlakuan A (direndam air) berpengaruh sangat nyata $(\mathrm{P}<0.01)$ terhadap perlakuan B, C, D dan E. Sedangkan perlakuan B berpengaruh tidak nyata $(\mathrm{P}>0.05)$ dengan perlakuan C, D dan E.
Pada perlakuan A memiliki total koloni bakteri tertinggi yaitu $37,95 \times 10^{5} \mathrm{CFU} / \mathrm{g}$, karena perlakuan perendaman dalam air, dimana tidak terdapat aloin dan saponin, yang merupakan zat anti bakteri dan anti jamur yang terdapat pada daging lidah buaya sehingga terjadi penguapan gas dan udara, memudahkan masuknya bakteri ke dalam telur dan mengakibatkan aktifitas mikroorganisme meningkat dibandingkan dengan perlakuan yang menggunakan larutan lidah buaya. Menurut Muchtadi (2009) kerusakan telur diakibatkan oleh keluarnya air dan karbondioksida $\left(\mathrm{CO}_{2}\right)$ dari telur selama penyimpanan. Hasil penelitian Novia et al. (2014) didapatkan telur asin kontrol tanpa perendaman dalam air sisa penirisan getah gambir setelah 7 hari dengan total koloni bakteri 47,80x10 $10^{5} \mathrm{CFU} / \mathrm{g}$.

Rendahnya total koloni bakteri pada perlakuan B (lidah buaya: air, 1:2) disebabkan oleh aloin dan saponin sebagai anti bakteri yang terdapat dalam konsentrasi larutan lidah buaya, aloin dan saponin berfungsi sebagai anti septik yang membunuh bakteri. Menurut Nejatzadah and Barandozi (2013) lidah buaya dapat menghambat pertumbuhan bakteri gram positif Sigella flexnori dan Streptococcus progenies terutama oleh anthraquinon (aloin) dan dihydroxyanthraquinones (saponin) yang memiliki aktifitas antibakteri. Ditambahkan oleh Narsih et al. (2012) kandungan aloin dalam lidah buaya 4,27\% dan saponin 5,43\% .

Berbeda tidak nyatanya perlakuan B, C, $\mathrm{D}$ dan $\mathrm{E}$ terhadap total koloni bakteri disebabkan oleh perendaman dalam larutan lidah buaya sudah menghambat perkembangbiakan bakteri. Nazaruddin (2009) menyatakan bahwa aloin dan saponin tidak menutupi pori-pori kulit telur tetapi mempunyai efek anti bakteri dan jamur. Hal ini akan mempertahankan keawetan telur asin yang dihasilkan, sehingga total koloni bakteri yang dihasilkan berada pada kisaran $4,7 \times 10^{5} \mathrm{CFU} / g$ sampai dengan $6,45 \times 10^{5} \mathrm{CFU} / \mathrm{g}$, dimana kisaran ini masih aman untuk dikonsumsi.

\section{Umur Simpan}

Hasil penelitian yang telah dilakukan, maka didapatkan rataan umur simpan telur 
asin yang direndam dengan konsentrasi larutan lidah buaya berkisar antara 16 hari sampai dengan 19 hari. Rataan umur simpan telur asin pada penelitian ini dapat dilihat pada Tabel 1.

Berdasarkan hasil analisis keragaman nilai umur simpan pada perlakuan menunjukkan hasil yang berbeda sangat nyata $(\mathrm{P}<0.01)$. Pada Tabel 1 dapat dilihat umur simpan telur asin hasil penelitian. Perlakuan A merupakan telur asin direndam dalam air, dimana poripori kulit telur masih terbuka sehingga cepat rusak dan hanya bertahan 6 hari karena poripori kulit telur masih terbuka akibatnya terjadi penguapan karbondioksida $\left(\mathrm{CO}_{2}\right)$ dan peningkatan aktifitas mikroorganisme yang dapat mempersingkat umur simpan dari telur asin. Umur simpan telur asin dengan konsentrasi larutan lidah buaya B (lidah buaya: air, 1:2) dapat memperpanjang umur simpan telur asin hingga 19 hari, $C$ (lidah buaya: air, 1:3) memperpanjang umur telur asin 18 hari, D (lidah buaya : air, 1:4) memperpanjang umur simpan telur asin 17 hari dan E (lidah buaya : air, 1:5) memperpanjang umur simpan telur asin 16 hari, hasil ini menunjukkan umur simpan yang berbeda sangat nyata, bervariasi sesuai dengan perbandingan konsentrasi larutan lidah buaya dan air yang diberikan.

Hal ini disebabkan aloin dan saponin yang terkandung dalam konsentrasi larutan lidah buaya juga tidak menutupi pori-pori kulit telur akan tetapi mencegah masuknya bakteri yang menyebabkan terjadinya kerusakan pada telur asin. Hasil penelitian Nejatzadah and Barandozi (2013) lidah buaya dapat menghambat pertumbuhan bakteri gram positif terutama oleh anthraquinon (aloin) dan dihydroxyanthraquinones (saponin) yang memiliki aktifitas antibakteri. Ditambahkan oleh Narsih et al. (2012) kandungan aloin dalam lidah buaya $4,27 \%$ dan saponin $5,43 \%$. Menurut Muhammad dan Margareth (2010), lidah buaya berkhasiat sebagai anti septik, anti jamur dan anti bakteri. Oleh sebab itu, telur asin yang direndam dalam konsentrasi larutan lidah buaya dapat disimpan lebih lama.

Data hasil dari kadar air dan $\mathrm{pH}$ samasama berbeda tidak nyata terhadap semua perlakuan, data total koloni bakteri pada kon- sentrasi larutan B (lidah buaya : air, 1:2) berbeda tidak nyata dengan perlakuan $\mathrm{C}$ (lidah buaya : air, 1:3), D (lidah buaya : air, 1:4), dan E (lidah buaya : air, 1:5), sedangkan perlakuan A kontrol direndam dalam air data total koloni sejalan dengan parameter umur simpan, setiap perlakuan menunjukkan berbeda sangat nyata, ini berarti bahwa perlakuan B merupakan perendaman yang efisiensi untuk mengawetkan telur asin. Hasil penelitian Novia et al. (2014) telur asin perendaman dalam air sisa penirisan getah gambir selama 1 jam tanpa pengenceran memiliki umur simpan sampai 63 hari.

\section{KESIMPULAN}

Hasil penelitian perendaman telur dalam larutan lidah buaya (Aleovera barbadensis Miller) menurunkan total koloni bakteri dan umur simpan dibandingkan control (tanpa perendaman) $(\mathrm{P}<0,1)$, namun tidak mempengaruhi kadar air dan $\mathrm{pH}(\mathrm{P}>0.05)$. Perendaman dalam larutan lidah buaya (lidah buaya : air, 1:2) menghasilkan nilai terbaik terhadap kadar air $64,74 \pm 1,60 \%, \mathrm{pH} 7,53 \pm 0,26$, total koloni bakteri $4,79 \pm 0,62 \times 10^{5} \mathrm{CFU} / \mathrm{g}$ dan umur telur asin 19 hari.

\section{DAFTAR PUSTAKA}

Apriyantono, D. Fardiaz, N. I. Puspitasari, Sedarwati dan S. Budiyanto. 1998. Analisis Pangan. Institut Pertanian Bogor. Bogor.

Arunlertaree, C., W. Kaewsomboon, A. Kumsopa, P. Pokethitiyooh and P. Panyawathanakit. 2007. Removal of lead from battery manufacturing wastewater by egg shell. Songklanakarin J. Sci. Technol. 29(3):857-868

Buckle, K. A., R. A. Edwards, G. H. Fleet dan M. Wootton. 2009. Ilmu Pangan. Terjemahan Hari Purnomo dan Adiono. UIPress. Jakarta.

Harlina, P.W., Ma Mei Hu, A.M. Legowo and Y.B. Pramono. 2012. The effect of supplementation garlic oil as an antibac- 
terial activity and salting time on the characteristic of salted egg. Journal of Applied Food Technology. 1(4):121-128

Josep, B and S. Justin Raj. 2010. Pharmacognostic and phytochemical properties of Oleo vera Linn-an overview. International Journal of Pharmaceutical Sciences Review and Research 4(2):106-110

Muchtadi, D. 2009. Prinsip Teknologi Pangan Sumber Protein. Cetakan Kesatu. Penerbit Alfabeta. Bandung.

Muhammad, A. dan Margareth. 2010. Kamus Pintar Obat Herbal. Nuha Media. Yogyakarta.

Narsih, S.Kumalaningsih, Wignyanto and S. Wijana. 2012. Identification of aloin and saponin and chemical composition of volatile constituents from Aloe vera (L) Peel. J.Agric.Food.Tech. 2(5):79-84

Nazaruddin. 2009. Obat Murah Alami dan Berkhasiat. Better Book. Jakarta.

Nejatzadeh, F and Barandozi. 2013. Antibacterial activities and antioxidant capacity of Aloe vera. Organic and Medical Chemistry Letter. 3(5):1-8

Novia, D., I.Juliyarsi dan P. Andalusia. 2011. Evaluasi total koloni bakteri dan cita rasa telur asin dengan perlakuan perendaman ekstrak kulit bawang (Allium ascalonicum). Jurnal Peternakan Indone-
sia,Volume 13 Nomor 2 Edisi Juni 2011 ISSN : 1907-1760. Hal : 92-98.

S. Melia, A. Sukma dan F. D. Rizki. 2012. Effects of soaking duration of briny eggs in gambier waste liquid on water, protein content and shelf life. Proceeding Poultry International Seminar 11-12 September 2012. hal : 383385

I. Juliyarsi, A. Sandra, Yuherman and R. Muhammad. 2014. Soaking salted egg in gambier liquid waste inhibit bacterial growth. Pak. J. Biol. Sci. 17(3):424-428

Nurhidayat, Y., J. Sumarmono dan S. Wasito. 2013. Kadar air, kemasiran dan tekstur telur asin ayam iaga yang dimasak dengan cara berbeda. Jurnal Ilmiah Peternakan. 1(3):813-820

Steel, R. G. dan J. H. Torrie. 1995. Prinsip dan Prosedur Statistik Suatu Pendekatan Biometrik. Cetakan ketiga. Terjemahan Bambang Sumatri. PT. Gramedia Pustaka Utama. Jakarta.

Syarief, R., S. Santausa dan S. Isyana. 1989. Teknologi Pengemasan Pangan. Pusat Antar Universitas, Institut Pertanian Bogor. Bogor.

Warisno. 2005. Membuat Telur Asin Aneka Rasa. Agro Media Pustaka. Jakarta. 